\title{
Sibylle Gielen
}

EIN MENSCH WIE KASPAR H. - PERFORMANCE (1990)

Bei der Ansbacher Kaspar-Hauser-Woche im Juli 1990 gelangte eine Performance der holländischen Künstlerin Sibylle Gielen zur Aufführung. Stilisierte Stellvertreterfiguren: die Frau, der Mann, das Mädchen, der Junge erweisen sich als ebenso gefangen im Netz nicht gelingender Kommunikation wie 'Kaspar H.`. Über allen Bildpartikeln liegt verwirrende Vieldeutigkeit, die Performance "fügt sich zur hermetischen Hauser-Passion«. [67]

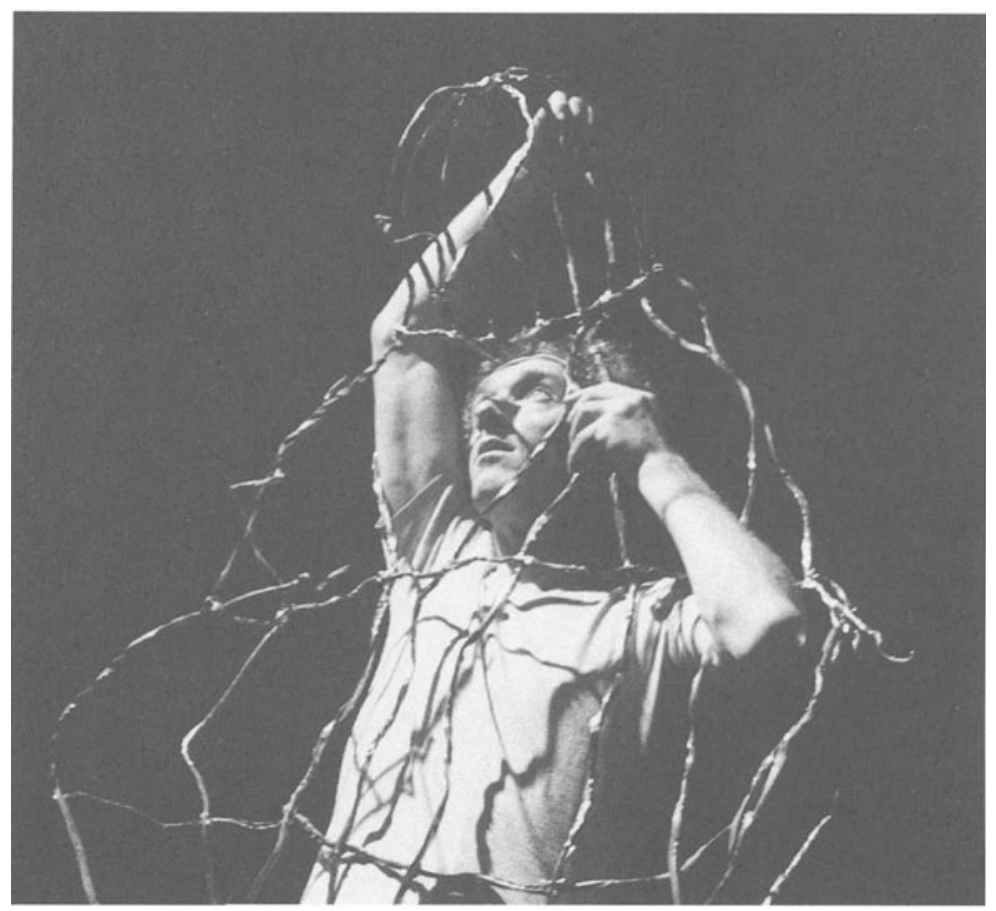

